Eastern Illinois University

The Keep

Faculty Research \& Creative Activity

Biological Sciences

January 2012

\title{
Seed biology of Physaria ludoviciana (silvery bladderpod; Brassicaceae ), an endangered species in sand prairies of the Midwest
}

\author{
Marissa C. Grant \\ Eastern Illinois University \\ Ann E. Claerbout \\ University of Illinois at Urbana-Champaign \\ Janice M. Coons \\ Eastern Illinois University \\ Henry R. Owen \\ Eastern Illinois University, hrowen@eiu.edu
}

Follow this and additional works at: http://thekeep.eiu.edu/bio_fac

Part of the Biology Commons

\section{Recommended Citation}

Grant, Marissa C.; Claerbout, Ann E.; Coons, Janice M.; and Owen, Henry R., "Seed biology of Physaria ludoviciana (silvery bladderpod; Brassicaceae ), an endangered species in sand prairies of the Midwest" (2012). Faculty Research \& Creative Activity. 86. http://thekeep.eiu.edu/bio_fac/86 


\title{
Seed biology of Physaria ludoviciana (silvery bladderpod; Brassicaceae), an endangered species in sand prairies of the Midwest ${ }^{1}$
}

\author{
Marissa C. Grant ${ }^{2,3}$ \\ Department of Biological Sciences, Eastern Illinois University, Charleston, IL 61920
}

Ann E. Claerbout

Department of Natural Resources and Environmental Sciences, University of Illinois at UrbanaChampaign, Urbana, IL 61801

Janice M. Coons

Department of Biological Sciences, Eastern Illinois University, Charleston. IL 61920 and Department of Natural Resources and Environmental Sciences, University of Illinois at Urbana-Champaign, Urbana, IL 61801

Henry R. Owen

Department of Biological Sciences, Eastern Illinois University, Charleston, IL 61920

\begin{abstract}
Grant, M. C. (Department of Biological Sciences, Eastern Illinois University, Charleston, IL 61920), A. E. Claerbout (Department of Natural Resources and Environmental Sciences, University of Illinois at Urbana-Champaign, Urbana, IL 61801), J. M. Coons (Department of Biological Sciences, Eastern Illinois University, Charleston, IL 61920 and Department of Natural Resources and Environmental Sciences, University of Illinois at Urbana-Champaign, Urbana, IL 61801), and H. R. OwEN (Department of Biological Sciences, Eastern Illinois University, Charleston, IL 61920). Seed biology of Physaria ludoviciana (silvery bladderpod; Brassicaceae), an endangered species in sand prairies of the Midwest. J. Torrey Bot. Soc. 139: 63-75. 2012.- Physaria ludoviciana (Nuttal) O'Kane \& Al-Shehbaz (silvery bladderpod) is a state endangered species in Illinois. Minnesota and Wisconsin, the eastern edge of its range. Our goal was to investigate its seed biology (production, dispersal, seed bank longevity, afterripening, seed longevity after storage using germination and emergence, and seedling establishment). This information will be useful for conservation efforts of this endangered species. Over a ten-year period, various seed biology parameters were measured. Infructescences were counted to estimate seed production with 110-744 seeds per reproductive plant. Soil samples were collected at various distances to estimate dispersal where seeds dispersed less than a meter, and also at various times to estimate longevity in the seed bank where only $4 \%$ as many seeds were found in November as in June. After-ripening tests used seeds imbibed every two months after harvest for ten months where germination rates increased when imbibition was delayed at least six months. Germination and emergence of stored seed was measured to estimate longevity. Seeds stored at $4{ }^{\circ} \mathrm{C}$ and $40-50 \%$ relative humidity remained viable for at least six years. For establishment and plant density, seedlings, vegetative plants, and reproductive plants were counted. For establishment, densities were $0-11$ seedlings $\mathrm{m}^{2}{ }^{2}$. This seed biology information could be applied to conservation efforts for this endangered species.
\end{abstract}

Key words: endangered species, Lesquerella ludoviciana, plant conservation, sand prairie, seed biology.

1 Funding was in part from the Illinois Department of Natural Resources - Illinois Wildlife Preservation Fund and from the Undergraduate Research Fund of the Department of Biological Sciences, Eastern Illinois University.

2 The authors thank S. Beach, J. Franklin, J. Nohren, and E. Smith for assistance with data collection for years 1999 to 2002, and also A. Baluka, S. Clark, A. King, K. Kowles, L. Ludwig, S. Malehorn, J. Minol, S. Nannapaneni, M. Tonsor, and $\mathrm{K}$. Yoon for assistance with seed counts. Also thanks to B. Alison and staff at JFNew, a native plant nursery, for assistance with sorting soil samples for seed extraction.

3 Author for Correspondence: E-mail: mgrant39493(a) lakeland.cc.il.us

Received for publication June 18, 2011, and in revised form December 1, 2011.
Physaria ludoviciana (Nuttal) O'Kane \& AlShehbaz (silvery bladderpod; Brassicaceae), formerly known as Lesquerella ludoviciana until Al-Shehbaz and O'Kane (2002) transferred it to the genus Physaria based on molecular evidence, is distributed from Illinois north to Wisconsin, west to Montana, south to Nevada, and east to Illinois. It is listed as an endangered species in Illinois (Herkert and Ebinger 2002, Illinois Department of Natural Resources 2010), Minnesota (Minnesota Department of Natural Resources 1996) and Wisconsin (Wisconsin Department of Natural Resources 2004). However, Claerbout (2003) found no $P$. ludoviciana plants at its single reported location in Wisconsin. In each of 
these states, $P$. ludoviciana exists in only one county. In Illinois, the population occurs on the eastern-most edge of its geographic range (Rollins and Shaw 1973), and it is the most vigorous compared to other surveyed populations in Colorado, Minnesota, Nebraska, and North Dakota (Claerbout 2003, Grant 2010). In other more western states, the species is scattered in widely separated, individual populations (USDA, NRCS 2010). These populations are infrequent and disjunct, where it is commonly found in well-drained, mobile sand in blowouts of sand prairies such as vegetated sand dunes (Claerbout 2003, Grant 2010).

Physaria ludoviciana is a perennial forb that forms a rosette of linear, basal leaves covered by thick trichomes, which gives the plant a silvery appearance. Flower stalks elongate as flower buds form, and yellow flowers are produced acropetally. Physaria ludoviciana flowers from April into August across its range (Rollins 1939, Rollins and Shaw 1973). However, flowering occurs April to May in Illinois, and mature seeds are shed in June. No fruit developed on self-pollinated inflorescences, suggesting it is self-incompatible (Claerbout et al. 2007). In the field, $P$. ludoviciana plants were visited by insect species from at least five different orders (Claerbout et al. 2007). Limited information is published on the seed biology of this species. Understanding the requirements for reproduction of $P$. ludoviciana from seed would allow for better management of this species.

Potential adaptations of Physaria ludoviciana to an open sand environment could involve seed production and dispersal. Setting seed in late spring may be beneficial because temperatures are lower and water is more plentiful than in later summer months. Physaria ludoviciana plants successfully produced fruits from May to June at the Henry Allan Gleason Nature Preserve (HAGNP) in Mason County, Illinois (Claerbout et al. 2007). High fruit production was reported in the related Physaria (as Lesquerella) fendleri, a desert perennial species, that can produce several hundred fruits per plant with $1-30$ seeds per fruit (Cabin and Marshall 2000). However, the related Physaria (as Lesquerella) arctica (Wormsk. ex Hornem.) S. Watson, a typical arctic perennial herb, only produced $3-8$ flowers per inflorescence, and 6-8 seeds per fruit (Aiken et al. 1999). In P. arctica, seeds often are dispersed only a short distance, due to the lack of adaptations for movement by wind; thus seedlings often occur in the vicinity of a parent plant (Marchand and Roach 1980, Elberling 2000).

Whether Physaria ludoviciana is able to maintain a persistent soil seed bank is unknown. Other related species, like Physaria fendleri, do maintain a seed bank (Hyatt et al. 1999). Seed banks benefit populations by providing a mechanism for dispersal through time (Evans and Cabin 1995). Studies on Helenium virginicum S.F. Blake, a federally protected species listed as threatened, found that the soil seed bank is a major contributor to long-term persistence of populations (Adams et al. 2005). Persistent seed banks usually are found where environmental and/or disturbance regimes are unpredictable, and thus the probability of seedling recruitment is low or variable (Parker et al. 1989). While $P$. ludoviciana lives in such disturbed regimes and would benefit from an ability to maintain a seed bank, Claerbout (2003) found no seeds in the seed bank as estimated by emerged seedlings from soil core samples collected near reproductive plants. This lack of seeds was not expected given the presence of seedlings and the diversity of age structure in the population. It is possible that dispersed seeds could be lost to vertebrate predators (Louda 1989, Crawley 1992).

Seeds of Physaria ludoviciana do not require cold stratification or scarification to germinate, but it is unclear if they experience dormancy after being shed which may be overcome with afterripening, a process where dormancy is progressively lost (Black et al. 2006). Previous germination studies on Physaria (as Lesquerella) gordonii (A. Gray) S. Watson found that seeds did not germinate readily (only $8 \%$ germination) (Barton 1936) and that dormancies for 5 or 6 years after harvest were common (Bass et al. 1966, Sharir and Gelmond 1971). If no afterripening is required to break dormancy, the large quantity of seeds produced presumably creates a greater chance of germination and establishment of seeds during the early summer rains than if dormancy is present. Physaria (as Lesquerella) fendleri (A. Gray) S. Watson has an annual dormancy-nondormancy cycle, and seeds had a maximum of $30 \%$ germination in year one and $95 \%$ in year two (Hyatt et al. 1999). The dormancy cycle of $P$. ludoviciana needs to be investigated. 
If proper environmental conditions are not present, seedling establishment may not occur every year. Since no seeds were found in the seed bank when sampled after seeds had shed in June, the expansion of Physaria ludoviciana populations could be limited from year to year (Claerbout 2003). Seed survival within the seed bank has large effects on the population growth rate for threatened species (Adams et al. 2005). Seedlings are present at HAGNP. but it is unknown whether seedling establishment is increasing or decreasing over successive years. For plants, a short window of time often occurs when conditions are favorable for successful germination and seedling establishment. Thus, the timing of germination when environmental conditions are favorable is a critical aspect of the fitness of a species, and it can be a limiting factor in growth, development, and reproduction of plants (Elberling 2000, Walck et al. 2005). In addition, an environment with unstabilized blowing sand, such as the sand prairie, could bury seeds and not allow them to germinate (Martinez and Moreno-Casasola 1993).

The goal'of this study was to investigate the seed biology of Physaria ludoviciana, including seed production, seed dispersal, seed longevity in the soil, afterripening, seed longevity during storage, and seedling establishment in the field. In this study, various aspects of seed biology were compared in three colonies of $P$. ludoviciana at HAGNP in Illinois to advance the conservation effort for this endangered species.

Materials and Methods. SITE DESCRIPTION. One of the most studied populations of Physaria ludoviciana is in Illinois at the HAGNP in Mason County (Herkert and Ebinger 2002). This preserve has a unique habitat that was formed during the last glacial retreat, when sand was deposited along the Illinois River (Gleason 1910). HAGNP is located in extreme northwestern Mason County, southwest of Goofy Ridge, and about $15 \mathrm{~km}$ northeast of Havana, Illinois (SE 1/4 Section 6, NE 1/4 Section 7, Township 22N Range 7W; McClain et al. 2005). The site lies within the Illinois River Section of the Mississippi River and the Illinois River Sand Area Natural Division, and it is within the Sand Ridge State Forest (Schwegman 1973). At the preserve, $P$. Iudoviciana grows on remnant sand dunes that are fully exposed and have been eroded by the wind into three distinct bowl-shaped depressions (Claerbout 2003). The blowouts where $P$. ludoviciana occurs on the dunes are situated in a more exposed environment. Three distinct colonies are spatially separated in depressions described as the North Colony Lower Bowl (NCLB), the North Colony Upper Bowl (NCUB), and the South Colony (SC). Of these three colonies, the NCLB is a stabilized blowout where the largest colony of $P$. ludoviciana is located. It is immediately west and below the highest peak of Devil's Tower, which is more than $25 \mathrm{~m}$ tall (McClain et al. 2005).

Seed Production. Seed production was surveyed at the HAGNP in the three colonies (NCLB, NCUB, and SC) in 1999 (8 June), 2000 (4 May, 1 June), 2001 (14 May, 6 June), 2002 (3 June), 2007 (4 June) and 2008 (26 June), although not at every colony on every date. On each date, $30-50$ plants in the reproductive stage were selected throughout the colony to count the numbers of flower stalks per plant, pedicels per stalk, flowers per stalk, fruits per stalk, and fruits with holes per stalk (fruit apparently damaged from herbivory). The term flower stalk refers either to inflorescences or to infructescences. Twentyfive fruits were collected from each of four representative plants to determine seeds per fruit. In the lab, the numbers of seeds in each set of 25 fruits were counted. For an estimate of the maximum number of seeds per plant, calculations were made by multiplying the number of seeds per fruit, by pedicels per stalk, by number of flower stalks per plant based upon the assumption that each pedicel had the potential to develop a fruit. A minimum seed estimate was calculated using number of fruits present per stalk, rather than pedicels per stalk. Means and standard errors were calculated for all measured parameters.

Seed Dispersal and Longevity in Seed BAnk. To estimate seed dispersal, soil was collected directly adjacent to 10 reproductive Physaria ludoviciana plants, and at 1 and $2 \mathrm{~m}$ away from each plant, taking care to be in relatively open areas. Samples were collected on 26 June 2008 from the NCLB, when $P$. ludoviciana was shedding its seeds. For each plant, a set of samples at each distance was taken. For each sample, soil was collected using an ice scraper to collect the top $2 \mathrm{~cm}$ of 
sand $(10 \times 10 \mathrm{~cm})$ into a dustpan. Reproductive plants at least $2 \mathrm{~m}$ apart were selected. Soil samples were placed into Ziploc ${ }^{\circledR}$ bags, and air dried individually in plastic trays $(10 \times 20 \times$ $6 \mathrm{~cm}$ ) for at least 7 days. Two soil samples were combined to make one replicate of sufficient volume, for a total of five replicates at each distance. These soil samples then were sent to JFNew Native Plant Nursery (Walkerton, Indiana, USA) where seeds were separated from sand using two steps on screen seed cleaning machines, where one step used seed mass, size and shape, while the other step used a moderately high air flow through the samples in combination with decreasing screen sizes to direct $P$. Iudoviciana seeds to the lowest collection tray. A Clipper 2 Seed Cleaner was used which forced air from below to separate seeds through a number of screens. The top screen was ASTM (American Society of Testing Materials) $1 / 14$ (1.40 $\mathrm{mm}$ opening), where materials not passing through this screen included larger debris such as $P$. ludoviciana seed pods. The bottom screen was ASTM $1 / 18(1.00 \mathrm{~mm})$, where materials passing through it were small, such as sand particles and dust. Materials collected from the bottom base tray and sieves were screened for final separation. All other materials were collected in the air-blow-dust collection port; these materials were inspected and added to bulk sample remnants. Material from the bottom base tray was further separated using brass sieve trays [ASTM 1/10 (1.85 mm), 1/12 $(1.70 \mathrm{~mm}), 1 / 14(1.40 \mathrm{~mm}), 1 / 18(1.00 \mathrm{~mm})$, $1 / 25(0.6955 \mathrm{~mm})$, and $1 / 35(0.485 \mathrm{~mm})]$. Physaria ludoviciana seed was separated between the 1/14 and 1/18 sieve trays and placed in plastic Ziploc ${ }^{\circledR}$ bags. Material from all other sieve screens was inspected and placed with other bulk sample remnants. These techniques proved effective to separate $P$. Iudoviciana seed by controlled feasibility tests, where a known number of added seeds were effectively separated from soil. The numbers of seeds per square meter were determined along with means and standard errors.

Seed longevity was measured at the NCLB to determine how long seeds remain in the seed bank. Twenty soil scrapes were collected in 2008 on both early and late sampling dates (26 June and 4 November), near 20 reproductive plants, and placed in Ziploc ${ }^{\circledR}$ bags. These samples were air dried for at least 7 days and four samples were combined together to make five replications for each sampling date that were sent to JFNew where they were separated using the same technique as for dispersal. The numbers of seeds per square meter were determined along with means and standard errors.

Seed Dormancy and Afterripening. Seeds were collected from the NCLB on 4 June 2007. The first germination tests were started on 12 June 2007, with additional tests initiated every 2 months until April 2008. Petri dishes (100 $\times$ $15 \mathrm{~mm}$ plastic, Fisherbrand ${ }^{\circledR}$, Pittsburg, PA) contained two sheets of $90 \mathrm{~mm}$ diameter filter paper (Whatman \#1, Fisherbrand ${ }^{\circledR}$, Pittsburg, PA) that were moistened with $5 \mathrm{ml}$ distilled water. Each trial had three dishes with 50 seeds each. Seeds were dusted with thiram powder $(50 \%$ tetramethylthiuram disulfide from Loveland Industries, Cambridge, Cambridgeshire, UK) to reduce fungal growth. Petri dishes were sealed with Parafilm ${ }^{\circledR}$ (Parafilm ${ }^{\circledR}$ "M" Laboratory film, Pechiney Plastic Packaging, Chicago, IL) and placed in a Rubbermaid ${ }^{\circledR}$ plastic tub $(33 \times 24 \times 10 \mathrm{~cm})$. These containers were placed in a Percival Scientific ${ }^{\circledR}$ (Perry, IA) seed germinator at 24.9 $\pm 0.0 \mathrm{C}$ (as recorded digitally by the chamber) with constant light provided by fluorescent bulbs at $18.8 \pm 1.0 \mu \mathrm{mol} \mathrm{m}{ }^{2} \mathrm{sec}^{1}$ as measured by an Apogee ${ }^{\circledR}$ Quantum meter (Logan, UT). Seeds were checked every three days to determine if additional water was needed to keep the seeds moist. The number of seeds germinated or contaminated (fungal) was recorded every 3 days for the first 6 months and then weekly for an additional 1 to 11 months, depending on when imbibition was started. If contamination was observed, contaminated seeds were dusted with additional thiram powder, which eliminated contamination. Seeds were considered germinated when the radicle emerged from the seed coat.

All ungerminated seeds were tested on 14 November 2008 with $0.5 \%$ of 2,3,5-triphenyl tetrazolium chloride (tetrazolium) to determine if they were viable. Seeds were placed in $100 \times 15 \mathrm{~mm}$ plastic Petri dishes with one sheet of $90 \mathrm{~mm}$ filter paper that was moistened with $3 \mathrm{ml}$ distilled water. Seeds were cut in half using a dissecting needle and a razor blade. When seeds were cut, the seed coat was broken so that the embryo and cotyledon were removed or at least exposed. Tetrazolium solution was dripped over seeds (Lakon 
1949). Petri dishes were placed in a Rubbermaid ${ }^{\circledR}$ tub covered with aluminum foil and a black garbage bag to keep light exposure to a minimum. The bag then was placed in the seed germinator at $25.0 \mathrm{C}$. Seeds were observed with a dissecting microscope for a color change at 6 and 24 hours after tetrazolium application. If seeds were alive/viable, the tetrazolium stained the seeds pink, and if the seeds were dead/not viable, no color change occurred.

Percentages of all seeds that germinated were calculated over 90 days, at 6 months, and at the end of this study. Percentages were also calculated for seeds that were alive and for those that were dead when tested with tetrazolium at the end of the study. Percentages were arcsin transformed to stabilize the variances. Arcsin transformed data also were analyzed by analysis of variance for months after harvest when imbibition began. ANOVA was followed by a Duncan's multiple range test at the 5\% level using SPSS (Version 16 for Windows) for germinated and ungerminated seeds.

Seed Germination after Storage. Germination trials included nine seed lots from different portions of seed stalks from harvests made in 1999-2002. Seeds were collected from the NCLB in 1999 ( 8 and 22 June), 2000 (1 and 16 June), 2001 (6 June), and 2002 (3 June). Seeds from the first collection dates in 1999 and 2000 and from the only collection in 2001 were separated into upper and lower stalk seeds. Seeds collected in 2002 were a mix of lower and upper stalk seeds. Seeds were stored in paper coin envelopes in a refrigerator (Isotemp Laboratory Refrigerator, Fisher Scientific, Pittsburg, PA) at $4{ }^{\circ}$ with 40 $50 \%$ relative humidity until used in this study. Four to five replications of each seed lot were used with 10-50 seeds for each replication. In earlier years total seed production of the population had not been estimated, so fewer replications and seeds were used relative to later years when seed production was known to be plentiful. Germination was tested in 2000 (11 April and 7 November), 2001 (11 November), 2002 (19 February), 2003 (20 February) and 2006 (19 January). Plastic Petri dishes containing two sheets of filter paper were moistened with $5 \mathrm{ml}$ of distilled water. Seeds were dusted with thiram powder before placing them on filter paper. Petri plates were sealed with Parafilm ${ }^{\circledR}$ and placed in a plastic tub which was placed in a seed germinator at $25.0 \pm 0.1 \mathrm{C}$ with constant light provided by fluorescent bulbs at $17.4 \pm 1.2 \mu \mathrm{mol} \mathrm{m}{ }^{2} \mathrm{sec}{ }^{~}$. Seeds were kept moist. The number of seeds germinated or contaminated (fungal) was recorded daily for 2 weeks. Seeds were considered germinated when the radicle emerged from the seed coat.

Means and standard errors were calculated for percentage germination for all seeds after two weeks. Percentages were arcsin transformed to stabilize the variances. Different seed lots were compared using analysis of variance on arcsin transformed data followed by a Duncan's multiple range test at the $5 \%$ level.

Seedling Emergence after Storage. Seeds were collected at the NCLB. One seed lot collected from each year 1999-2002 (22 June 1999, 16 June 2000, 6 June 2001, and 3 June 2002) was tested. These seed lots were chosen because germination trials started in January 2006 showed that these seeds had highest germination within each year. Seeds were stored in paper coin envelopes in a refrigerator at $4{ }^{\circ} \mathrm{C}$ with $40-50 \%$ relative humidity until used. Three repetitions were used for each seed lot with 25 seeds each. On 9 February 2006, seeds were planted in trays $(10 \times 20 \times 6 \mathrm{~cm})$ filled with soilless mix (peat, vermiculite, and perlite) (Fafard Growing Mix \#2, Conrad Fafard, Inc., Agawam, MA) and moistened with distilled water. Twenty-five seeds were placed in each tray. Seeds were planted $1 \mathrm{~cm}$ below the surface of the mix. Trays were placed in a growth chamber at $25.9 \pm 0.1 \mathrm{C}$ with a photoperiod of 16 hours of light from fluorescent and incandescent bulbs at $309 \pm$ $15 \mu \mathrm{mol} \mathrm{m}{ }^{2} \mathrm{sec}^{1}$. The number of emerged seedlings was counted daily for 4 weeks. Data on number of leaves and maximum width of basal rosette were recorded weekly. Plants were watered as needed with distilled water. Fresh masses of shoots were weighed when plants were harvested after four weeks. Plants were dried in an oven for 24 hours at $111^{\circ} \mathrm{C}$ for dry mass measurements.

Means and standard errors were calculated for percentage emergence, number of leaves, width of plants, fresh mass and dry mass. Then, all parameters were analyzed by analysis of variance for seed lots collected each year. ANOVA was followed by a Duncan's multiple range test at the $5 \%$ level. 
Table 1. Estimated seed production using counts of reproductive structures of Physaria ludoviciana at Henry Allan Gleason Nature Preserve, Mason County, Illinois from 1999-2008.

\begin{tabular}{|c|c|c|c|c|c|c|c|c|}
\hline Ycar & Datc & Site & $\begin{array}{c}\text { Flower stalks/ } \\
\text { plant }\end{array}$ & Fruits/stalk & Pedicels/stalk & Seeds/fruit" & $\begin{array}{c}\text { Estimated } \\
\text { secds/plant } \\
\text { (based on fruit) }\end{array}$ & $\begin{array}{c}\text { Estimated seeds/ } \\
\text { plant (based on } \\
\text { pedicels) }\end{array}$ \\
\hline 1999 & 8 June & $\mathrm{NCLB}^{<}$ & $6.9 \pm 0.6^{\mathrm{w}}$ & $12.8 \pm 1.2$ & $\mathrm{ND}^{\mathrm{v}}$ & $2.5 \pm 0.4$ & 221 & ND \\
\hline 2000 & 1 June & NCLB & $3.1 \pm 0.6$ & $12.2 \pm 1.1$ & ND & $2.9 \pm 0.2 *$ & 110 & ND \\
\hline 2001 & 6 June & NCLB & $5.1 \pm 0.4$ & $11.4 \pm 0.7$ & ND & $2.9 \pm 0.2 *$ & 168 & ND \\
\hline 2002 & 3 June & NCLB & $6.2 \pm 0.6$ & $23.7 \pm 1.7$ & $30.9 \pm 2.1$ & $3.4 \pm 0.5$ & 500 & 651 \\
\hline 2007 & 4 June & NCLB & $6.2 \pm 0.4$ & $22.8 \pm 1.1$ & $30.9 \pm 1.4$ & $2.5 \pm 0.3$ & 353 & 479 \\
\hline 2008 & 26 June & NCLB & $6.7 \pm 0.6$ & $12.4 \pm 1.3$ & $34.7 \pm 2.3$ & $3.2 \pm 0.1$ & 266 & 744 \\
\hline 2008 & 26 June & $\mathrm{NCUB}^{y}$ & $5.3 \pm 0.6$ & $9.4 \pm 1.6$ & $29.7 \pm 2.8$ & $3.1 \pm 0.2$ & 154 & 488 \\
\hline \multirow[t]{2}{*}{2008} & 26 June & $\mathrm{SC}^{\mathrm{x}}$ & $4.3 \pm 0.5$ & $14.0 \pm 2.2$ & $31.1 \pm 3.0$ & $3.1 \pm 0.2$ & 187 & 415 \\
\hline & & & & & & Means & 248 & 555 \\
\hline
\end{tabular}

" seeds per fruit is the average of 25 fruits; * fruits were not collected, so values are the average of all other years.

ND $=$ No data was collected for 1999-2001.

" means \pm standard errors.

* South Colony.

N North Colony Upper Bowl

' North Colony Lower Bowl.

Seedling Establishment and Plant DensiTIES IN THE FIELD. Densities of Physaria ludoviciana seedlings, vegetative plants, and reproductive plants were counted for the three different colonies at the HAGNP in 2000 (1 June), 2001 (14 May, 2 June and 24 July), 2002 (6 May and 3 June), 2007 (4 June) and 2008 (30 April and 26 June). A 45-meter transect was extended through the center of each colony, with a quadrat $\left(0.25 \mathrm{~m}^{2}\right)$ being located directly adjacent on alternating sides of the transect at one meter intervals. The orientation of this transect varied depending on the size and shape of the colony. In the NCLB, the entire transect was extended from south to north. In the NCUB, two 30-meter transects extended from west to east and a 15-meter transect from south to north. In the SC, three 15-meter transects were parallel to each other and extended from west to east. In each of the quadrats, the numbers of seedlings ( $\leq 6$ leaves), vegetative plants ( $>6$ leaves, but no flower stalks) and reproductive plants (flower stalks) were counted. The number of plants per square meter at each growth stage was calculated. The percentage of plants at each growth stage also was calculated for each colony and year.

Results. Seed Production. Physaria ludoviciana produced between 110-744 seeds per reproductive plant (Table 1). The estimate based on fruit numbers is a minimum estimate because it only counted fruits present at the time of the survey. The estimate based on the number of flower pedicels is a maximum estimate because it assumed that every pedicel would produce a fruit. On 26 June 2008, when seed estimates were made that compared all three colonies, the NCLB had the highest number of seeds per plant (Table 1). The number of flower stalks per plant varied between years and colonies ranging from 2.1 and 6.7 (Figure 1), with averages across all years for flower stalks per plant being 4.8, 2.9, and 4.0, for NCLB, NCUB, and SC, respectively. Within each of the three colonies, flower stalk production was highest in June 2008 relative to earlier years (2000 and 2001) with 6.7, 5.3 and 4.3 stalks per plant in the NCLB, NCUB and SC, respectively (Fig. 1). Herbivory of seeds, as estimated by holes in fruits, ranged from $0.8-8.0 \%$ of fruits in $2002-2008$.

Seed Dispersal and Longevity in SEed BANK. Most seeds do not disperse far from the mother plant. When plants were shedding seeds in June, 380 seeds $\mathrm{m}^{2}$ found directly adjacent to a reproductive plant was significantly higher compared to 10 and 20 seeds $m$ 2 found at 1 and 2 meters, respectively, from reproductive plants (Table 2). Only $4 \%$ of the number of Physaria ludoviciana seeds present in June were found in November with a significant difference between seed numbers found in June compared to November (Table 2). The longevity of $P$. ludoviciana seeds in the seed bank is limited for the following seasons.

Seed Dormancy and Afterripening. Physaria ludoviciana seeds demonstrated a need 


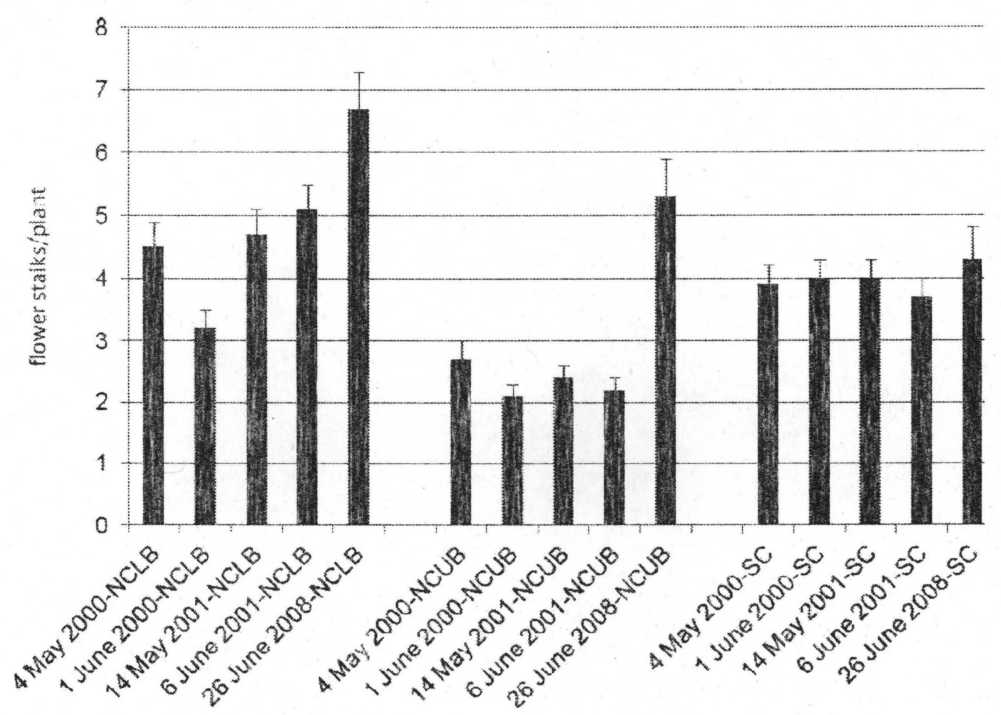

Fig. 1. Flower stalks per plant (means \pm standard errors) for Physaria ludoviciana in the North Colony Lower Bowl (NCLB), North Colony Upper Bowl (NCUB), and South Colony (SC) from 2000 to 2008 at the Henry Allan Gleason Nature Precerve, Mason County, IL.

for an afterripening period. Seed germination rates when seeds were imbibed at $0-4$ months after seeds were harvested were slow at the beginning, whereas when seeds were imbibed at $6-10$ months after seeds were harvested. rates increased and total germination percentages were higher (Figure 2). Germination percentages for seed imbibed at 6,8 , and 10 months after harvest were significantly higher than those imbibed at 0 and 4 months after harvest (Table 3). Germination percentages at 6 months after imbibition were highest for seeds started 10 months after harvest. At final percent germination, eventually germination percentages became more similar and most viable seeds had germinated (Table 3 ).

Table 2. Dispersal of Physaria ludoviciana seeds and longevity in the seed bank determined from surface soil samples $(2 \mathrm{~cm}$ depth) collected at the Henry Allan Gleason Nature Preserve, Mason County, Illinois on 26 June and 4 November 2008.

\begin{tabular}{ccc}
\hline & \multicolumn{2}{c}{ Sceds $\mathrm{m}^{2}$} \\
\cline { 2 - 3 } Meters from plant & \multicolumn{1}{c}{ June } & November \\
\hline 0 & $380 \pm 158 \mathrm{a}^{2 \cdot}$ & $15 \pm 15 \mathrm{~b}$ \\
1 & $10 \pm 10 \mathrm{~b}$ & $\mathrm{ND}^{\mathrm{x}}$ \\
2 & $20 \pm 12 \mathrm{~b}$ & ND
\end{tabular}

ND $=$ No data.

means within a column or row followed by different letters are significantly different based on Duncan's multiple range test at $P=0.05$ level.

means \pm standard errors.
Fungal contamination of the seed was less than $3 \%$, and did not interfere with germination. At final counts, all seeds were the same age and maturity.

Tetrazolium tests indicated that twenty percent of the seeds that were imbibed immediately after harvest, and had been in Petri dishes for 17 months, were not viable (Table 3). Tetrazolium tests showed that seeds started at 4 and 8 months after harvest had the highest percentage of viable seeds that had not geminated (Table 3).

Seed Germination after Storage. Germination was high after 6.5 years in dry storage $(4 \mathrm{C})$ as long as seeds were mature when collected. Some of the seed lots had significant increases in germination after being stored including the 16 June harvest upper stalk in 2000 and the 3 June harvest mixed stalk in 2002 (Table 4). The only significant decrease in germination after being stored was the 8 June harvest lower stalk seed in 1999. Seed from 2002 contained both mature and immature seed as both upper and lower stalks were mixed, thus possibly accounting for their low germination percentages. Seed remained viable in storage for at least 6.5 years.

Seedling Emergence after Storage. Emergence was first seen in seeds from 1999-2001 on day five after planting, whereas seedlings from 


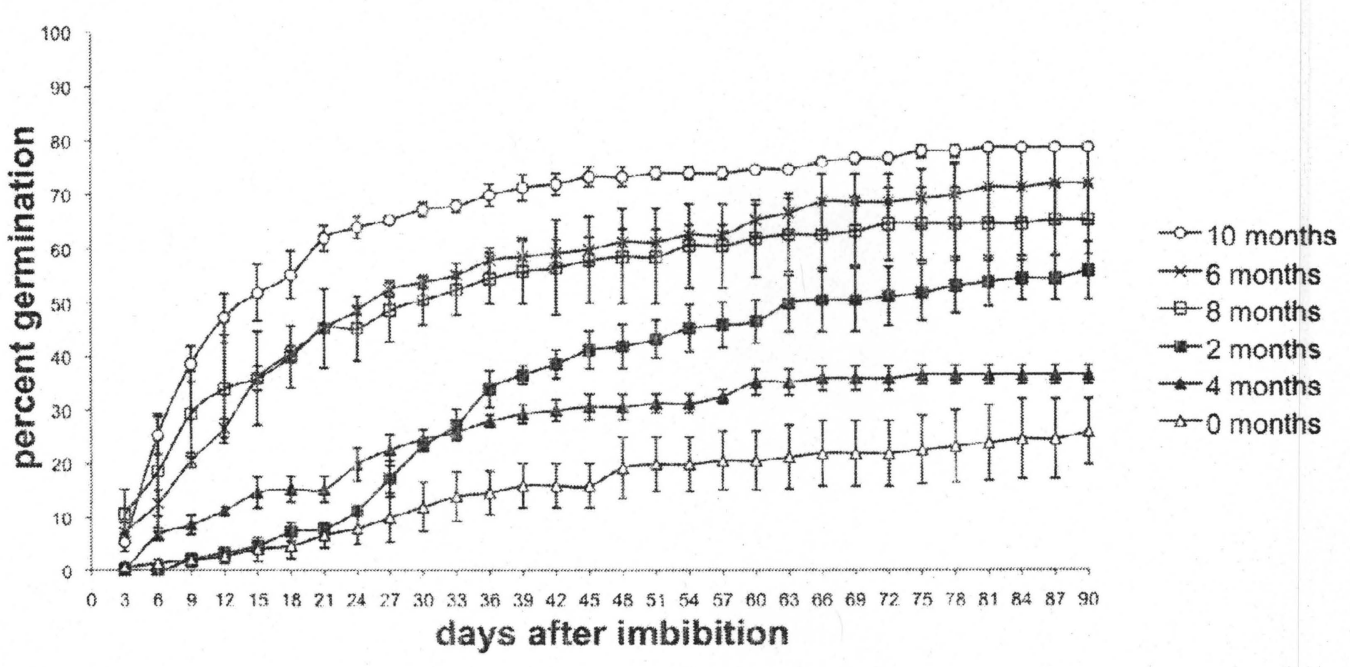

FIG. 2. Cumulative germination (\%) over 90 days for seeds of Physaria ludoviciana when imbibition started $0-10$ months after seeds were harvested (4 June 2007). Means \pm standard errors.

2002 seeds did not emerge until day six (Fig. 3). Four weeks after planting, seed from the 1999 upper stalk had the highest emergence ( $85.5 \%$ ), and seed from 2002 had the lowest emergence $(18.7 \%)$. Rosette widths varied as plants from seeds collected in 1999 and 2000 had greater widths than those from seeds collected in 2001 or 2002. The average number of leaves was not significantly different for plants grown from seed collected in different years. Fresh and dry masses of plants from 1999 seeds were highest, whereas those of plants from 2002 seeds were the lowest (Table 5).

Seedling Establishment and Plant DensiTIES IN THE FIELD. Seedling densities fluctuated between years. Density of seedlings was con- sistently higher at the NCLB than other colonies in every year and sampling month (Fig. 4). Seedlings were most numerous at the NCLB in June 2007 with 10.8 seedlings $\mathrm{m}^{-2}$, at the NCUB in June 2008 with 1.3 seedlings $\mathrm{m}^{2}$, and at the South Colony in June of 2000 with 1.2 seedlings $\mathrm{m}^{2}$. The NCLB also had the greatest number of vegetative plants compared to other colonies at all sampling times. For all three colonies, vegetative plants were the highest in June, except in 2008 when vegetative plants were highest in April at the NCLB and equal in April and June at the NCUB. Reproductive plants were highest at the NCLB, except in June 2000 when the SC had the greatest number of reproductive

Table 3. Percentage of Physaria ludoviciana seeds that germinated when imbibition began 0-10 months after harvest and the viability of ungerminated seeds.

\begin{tabular}{ccccc}
\hline \multirow{2}{*}{$\begin{array}{c}\text { Months after harvest } \\
\text { when imbibed }\end{array}$} & $\begin{array}{c}\text { \% germination at } \\
6 \text { months: }\end{array}$ & Final \% germination & Percent ungerminated \\
\cline { 3 - 5 } & $46.0 \pm 8.7 \mathrm{~d}^{\mathrm{k} . \mathrm{w}}$ & $78.7 \pm 4.8\left(17^{\mathrm{v}}\right) \mathrm{c}$ & $1.3 \pm 0.7 \mathrm{~b}$ & $20.0 \pm 4.2 \mathrm{a}$ \\
2 & $65.3 \pm 7.1 \mathrm{c}$ & $97.3 \pm 0.7(15) \mathrm{a}$ & $0.0 \pm 0.0 \mathrm{~b}$ & $2.7 \pm 0.7 \mathrm{c}$ \\
4 & $46.7 \pm 1.3 \mathrm{~d}$ & $82.7 \pm 5.3(13) \mathrm{c}$ & $12.7 \pm 3.7 \mathrm{a}$ & $4.6 \pm 1.8 \mathrm{bc}$ \\
6 & $84.7 \pm 3.5 \mathrm{ab}$ & $87.3 \pm 3.7(11) \mathrm{bc}$ & $0.0 \pm 0.0 \mathrm{~b}$ & $12.7 \pm 3.7 \mathrm{ab}$ \\
8 & $76.0 \pm 4.6 \mathrm{bc}$ & $88.7 \pm 5.5(9) \mathrm{abc}$ & $8.0 \pm 6.1 \mathrm{ab}$ & $3.3 \pm 2.4 \mathrm{c}$ \\
10 & $93.3 \pm 0.7 \mathrm{a}$ & $94.7 \pm 1.3(7) \mathrm{ab}$ & $2.7 \pm 1.3 \mathrm{~b}$ & $2.6 \pm 1.3 \mathrm{c}$ \\
\hline
\end{tabular}

' cotyledon and/or embryo did not turn pink after 24 hours in tetrazolium.

"cotyledon and/or embryo turned pink after 24 hours in tetrazolium.

value in parentheses is number of months after imbibition when final percentages determined.

" means within a column followed by different letters are significantly different based on Duncan's multiple range test at $P=0.05$ level using arcsin transformed data.

${ }^{\wedge}$ means \pm standard errors.

y 6 months after start of imbibition.

$<$ harvested on 4 June 2007. 


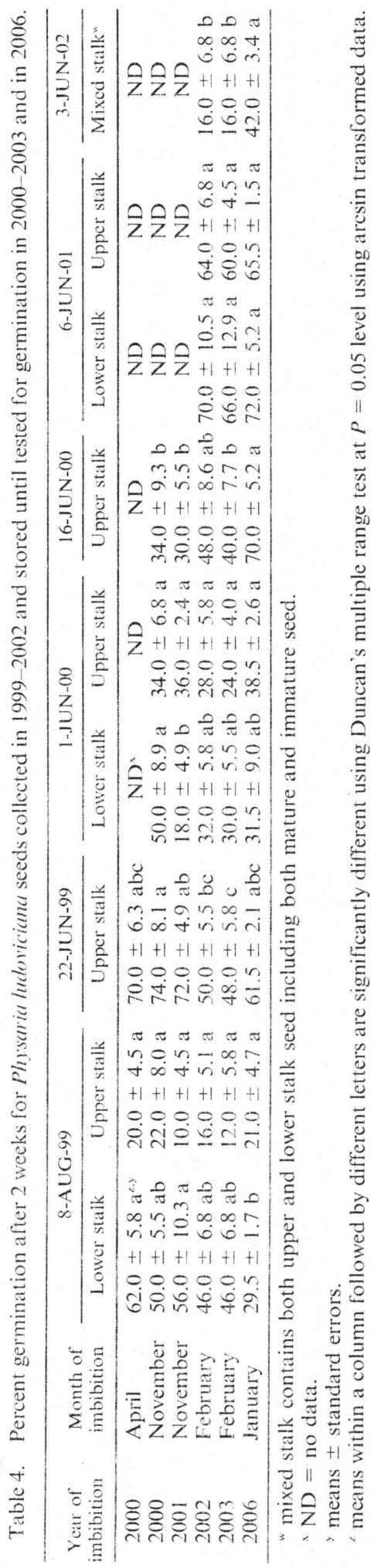

plants. The NCLB overall has the largest population with the greatest number of Physaria ludoviciana plants per $\mathrm{m}^{2}$. Figure 4 shows great variability in numbers of seedling, vegetative and reproductive plants at different sampling times for the three colonies. Seedlings often were found in close proximity to a reproductive plant.

Discussion. Seed availability is affected by various parameters including seed production, dispersal, and longevity in the soil. Seed production was variable from year to year, with plants producing 110-744 seeds per plant. The variability in seed production in different years could be due to environmental conditions such as rainfall, temperature, and light. However, production of seeds was similar to other species in this genus (Delph 1986, Cabin et al. 1998, Aiken et al. 1999). Delph (1986) hypothesized that high fruit set is an adaptive response to unpredictable, variable resource levels and high herbivory risk. Environmental conditions in the sand prairie containing the studied population of Physaria ludoviciana certainly are expected to provide variable resources, and holes in the fruits suggest a possible herbivory risk. When seed is produced in early June, other food options may be linited, so P. ludoviciana seeds may be a major food source for these predators. The percentage of holes per fruit varied between $0.8-8.0$ in populations of $P$. ludoviciana at the nature preserve during 2002-2008.

Although seed production was high, most seeds of Physaria ludoviciana did not disperse far from the mother plant as seeds $m^{2}$ in the seed bank were significantly lower at 1 or $2 \mathrm{~m}$ away than directly adjacent to the mother plant. According to Cabin et al. (1998), the vast majority of seeds in Physaria fendleri remain within $1 \mathrm{~m}$ of the parent. Physaria arctica is only able to disperse its seeds a short distance due to lack of dispersal adaptations (Marchand and Roach 1980). Physaria ludoviciana is unlikely to disperse its seeds far from the mother plant because no structures to facilitate widespread seed dispersal (greater than $1 \mathrm{~m}$ ) are apparent (Claerbout 2003). If seeds had mechanisms to disperse further, plants might appear in the apparently compatible sandy habitat present around these populations. Having no apparent structures to disperse its seeds great distances could be a limiting factor for the spread of $P$. ludoviciana at the edge of its geographical distribution. 


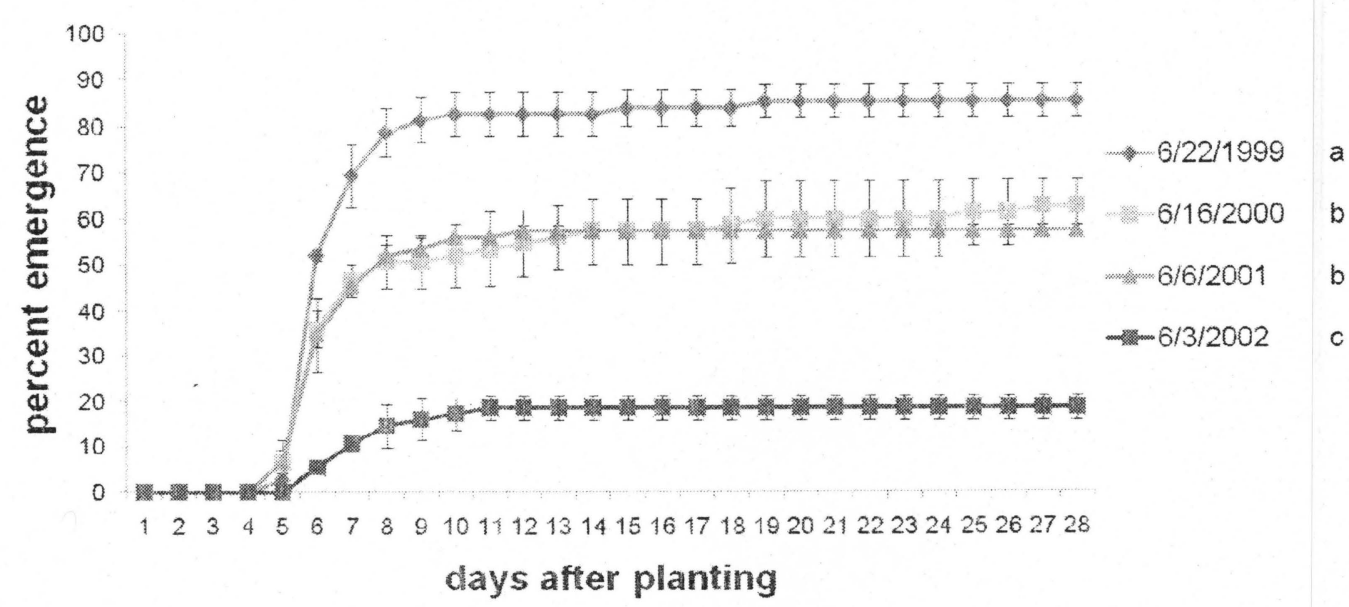

FIG. 3. Cumulative emergence $(\%)$ of seedlings over 28 days for seed lots of Physaria ludoviciana collected in 1999-2002 and stored until planting in February 2006. Means \pm standard errors. Means at 28 days followed by different letters are significantly different based upon Duncan's multiple range test at $P=0.05$ level.

For dispersed seeds, seed longevity in the seed bank was low as only $4 \%$ of the number of Physaria ludoviciana seeds found in June were still present in November, although when these seeds were shed is unknown. Other studies on seed banks of prairie species that compared seed production with the density of subsequent seed banks also found the great majority of new seeds fail to persist in the soil (Rabinowitz 1981). A study of the seed bank of Physaria fendleri with similar collection methods found as many as 247 seeds $\mathrm{m}^{2}$ in the soil after a normal fruiting year (Evans and Cabin 1995), which was lower than the 380 seeds $m^{2}$ in soil collected near mother plants during June in this study. According to Chen and Maun (1999), large losses of seed can occur during dispersal due to herbivory. In Physaria fendleri, desert granivores such as ants and rodents affected the population by eating seeds (Cabin and Marshall 2000). In sand desert systems, granivores are highly effective at finding and depleting relatively dense soil seed patches, and predator populations can increase rapidly following periods of high seed production (Cabin and Marshall 2000). Herbivory of $P$. ludoviciana seed is supported by other studies that found grassland plants often lose large numbers of dispersed seeds to vertebrate predators (Louda 1989, Crawley 1992). The decrease in seed numbers for $P$. ludoviciana in the seed bank suggests that they may fall victim to herbivory, possibly by rodents or insects. Hence, numerous factors including seed production, dispersal and longevity affect seed availability.

Of seeds that remain in the seed bank, seed dormancy would affect their ability to germinate. No stratification or scarification is required to break dormancy in Physaria ludoviciana (Claerbout 2003); however, seeds need an afterripening period. Germination tests of seeds started soon after harvest indicated that, if seeds are viable, they

Table 5. Width of rosettes, number of leaves, and fresh and dry masses of Physaria ludoviciana plants when harvested 28 days after planting. Seed was collected in 1999-2002 and planted in 2006.

\begin{tabular}{ccccc}
\hline Sced collection date & Width $(\mathrm{cm})$ & \# of leaves & Fresh mass $(\mathrm{g})$ & Dry mass $(\mathrm{g})$ \\
\hline 22-JUN-99 & $3.3 \pm 0.2 \mathrm{a}$ a.y & $5.8 \pm 0.2 \mathrm{a}$ & $0.86 \pm 0.03 \mathrm{a}$ & $0.148 \pm 0.009 \mathrm{a}$ \\
16-JUN-00 & $3.3 \pm 0.3 \mathrm{a}$ & $5.5 \pm 0.3 \mathrm{a}$ & $0.52 \pm 0.03 \mathrm{~b}$ & $0.093 \pm 0.004 \mathrm{~b}$ \\
6-JUN-01 & $2.7 \pm 0.3 \mathrm{~b}$ & $5.4 \pm 0.3 \mathrm{a}$ & $0.43 \pm 0.03 \mathrm{~b}$ & $0.071 \pm 0.007 \mathrm{c}$ \\
3-JUN-02 & $2.1 \pm 0.3 \mathrm{c}$ & $5.5 \pm 0.3 \mathrm{a}$ & $0.10 \pm 0.01 \mathrm{c}$ & $0.013 \pm 0.002 \mathrm{~d}$ \\
\hline
\end{tabular}

y means within a column followed by different letters are significantly different based on Duncan's multiple range test at $P=0.05$ level.

means \pm standard errors. 

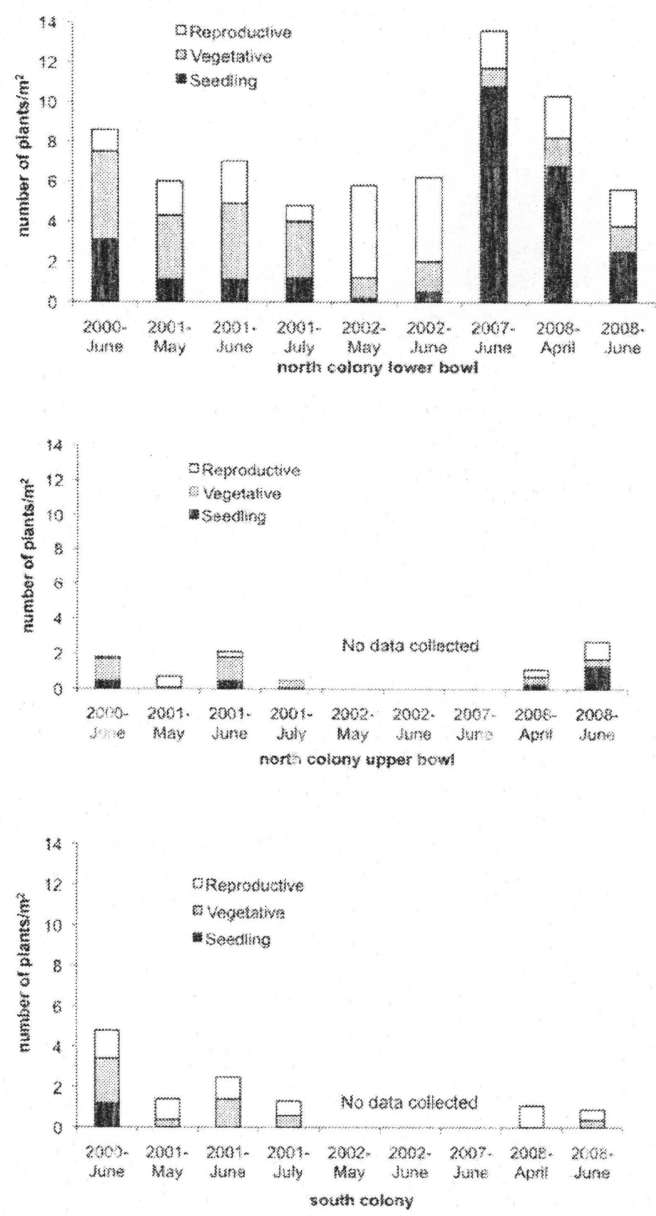

FIG. 4. Mean density of Physaria ludoviciana plants $\mathrm{m}=$ in the North Colony Lower Bow (NCLB), North Colony Upper Bowl (NCUB), and South Colony (SC) at the Henry Allan Gleason Nature Preserve, Mason County, Illinois at different developmental stages (reproductive, vegetative, and seedling) in different months from 2000-2008. In 2002 and 2007, no data were collected at the North Colony Upper Bowl and South Colony.

eventually germinate, and tetrazolium tests for metabolic activity showed that some of the ungerminated seeds still were alive. Dormancy is adaptive because it allows seeds to synchronize their germination with environmental conditions that favor their growth and development through reproduction, while reducing the chance of germinating at unfavorable times during the year (Hyatt et al. 1999). An increased likelihood of desiccation and high soil surface temperatures in summer, compared to spring or fall, may make summer less desirable for seedling establishment. Physaria fendleri had seedlings in the field in both spring and fall, depending on the amount and timing of rainfall (Cabin et al. 1998. Hyatt et al. 1999). Physaria ludoviciana seedlings were observed in the field in 2008 with densities of $6.8 \pm 1.7$ in the spring and of $1.3 \pm 0.7 \mathrm{~m}^{2}$ in the fall (Grant 2010). Seedling emergence in late fall could be detrimental if plants are not well established when entering winter, with its limitations in water availability and low temperatures. However, P. Iudoviciana plants are evergreen, so if seedlings are well established before winter, they should be able to survive the winter conditions. Physiological dormancies can be broken by afterripening in other Physaria (Lesquerella) species (Sharir and Gelmond 1971) especially with plants grown in unpredictable environments like deserts or sand prairies (Hyatt et al. 1999). Physaria ludoviciana could benefit potentially from this same dormancy strategy (timing of germination), especially because it establishes itself in areas that experience four seasons. Seeds that germinate at different times would have a selective advantage for $P$. Iudoviciana.

Seeds that require afterripening might be expected to store well, which could be beneficial for conservation efforts. Although few seeds persisted in seed banks in November at the nature preserve, seeds harvested and stored in a controlled environment at $4{ }^{\circ} \mathrm{C}$ and $40-50 \%$ relative humidity were able to survive for as long as 6.5 years when seeds were harvested in late June. Several factors affected their survival and germination after storage, including years in storage, initial maturity (as influenced by both harvest month and position on flower stalk), and harvest year. Seed maturity varied with harvest month and position on the flower stalk, which in turn affected seed viability (germination) after storage. In early June, seeds on the lower portion of the flower stalk are more fully developed than seeds on the upper portion of the flower stalk, due to acropetal flowering. Later in the seed production season (midJune), seeds remain only on the upper portion of the stalk (Claerbout 2003). After storage, high germination occurred in seeds from the upper portion of the stalk when collected in mid-June, but not in early June. This response is probably because seeds from the first collection date were not mature in the upper portion of the flower stalk. These findings are supported by other studies with weed species 
comparing seed germination to spikelet position that found significant differences in germination based on position on the stalk (Fandrich and Mallory-Smith 2006). Hence. differences in germination after storage often are related to initial seed maturity. Harvest year also affected germination after storage, when environmental stresses, such as low moisture or high temperature might negatively affect seed development. Hence, it is important to know when to collect mature seed, especially when seed is stored for future restoration efforts.

When storing seed, it is important to consider not only their viability, as measured by germination, but also their vitality, as measured by emergence. Emergence of Physaria ludoviciana seedlings varied greatly for seeds harvested between 1999-2002, and then stored until 2006. For all years, seeds examined for their emergence were from the last collection day of each year (all in June, although day of the month varied) and from the upper portion of the flower stalk, with the exception of the 2002 seed, which only had one early collection date containing mixed mature and immature seeds. Emergence rates for seeds collected from only the upper portion of the flower stalk $(1999,2000,2001)$ were faster than those from the mixed seed collection in 2002. Final emergence percentages were highest from seed collected in 1999 (on 22 June), intermediate from seed collected in 2000 (on 10 June) and 2001 (on 6 June), and lowest from seed collected in 2002 (on 3 June). These differences in rates and final percentages for emergence relate to initial seed maturity more than harvest year (i.e., age of seed) as seed maturity at collection would have been greatest in 1999 and least in 2002. based on seed harvest dates. A similar pattern was observed when vigor was measured by the development of seedlings (i.e., rosette widths, leaf numbers, and masses). The successful germination of seeds and emergence of seedlings after 6.5 years of storage indicates the potential usefulness of stored seeds for use in restoration.

Regardless of whether seeds remain in the seed bank, or are stored, seedling establishment is critical for the persistence of a population. Population persistence, as measured by plant densities, varied between the three colonies sampled at the Henry Allan Gleason Nature Preserve and between years. The NCLB had the highest number of seedlings per square meter, as well as vegetative and reproductive plants, compared to NCUB or SC, which indicates that the NCLB has the highest population density of the three colonies. However, seedling establishment was low and unpredictable between years in these colonies. Seedling densities ranged from 0.0 10.8 seedlings $\mathrm{m}^{2}$, which is lower than the number of seeds in the seed bank (380 seeds $\mathrm{m}^{2}{ }^{2}$ in June when seeds are being shed; 15 seeds $m^{2}$ in November), and much lower than the number of seeds produced (110-744 seeds/ plant). A combination of factors might have caused this low seedling establishment at HAGNP. In a sand dune system, survival of seedlings is affected by physical factors such as sand movement and desiccation (Martinez and Moreno-Casasola 1993). Burial of seeds by blowing sand is critical for the establishment of many species, but blowing sand might kill small seedlings of Physaria ludoviciana. In studies done by Martinez and Moreno-Casasola (1993) on a sand dune legume, one of the limiting factors for seedling establishment was sand movement. Smaller seedlings were the most susceptible to being buried or desiccated by sand. Hence, seedling establishment may be a limiting factor for $P$. ludoviciana. The variability in plant densities between years certainly puts this species at risk, and supports the importance of conservation activities for its long-term survival, especially in regions near the edge of its range. Therefore, knowledge about the seed biology of this species would aid in restoration efforts.

\section{Literature Cited}

AdAms, V. M., D. M. Marsh, AND J. S. Knox. 2005. Importance of the seed bank for population viability and population monitoring in a threatened wetland herb. Biol. Cons. 124: 425-436.

Aiken, S. G., M. J. Dallwitz, L. L. Consaul, C. L. McJannet, L. J. Gillespie, R. L. Boles, G. W. Argus, J. M. Gillett, P. J. Scott, R. Elven, M. C. Leblanc, A. K. Brysting, and H. Solstad. 1999. Flora of the Canadian Arctic Archipelago: descriptions, illustrations, identification, and information retrieval. Retrieved May 23, 2011 from < http://www.mun.ca/biology/delta/arcticf/>

Al-Shehbaz, I. A. and S. L. O'Kane. 2002. Lesquerella is united with Physaria (Brassicaceae). Novon 12: 319-329.

BARTON, L. 1936. Germination of some desert seeds. Contributions from Boyce Thompson Institute 8: 7-11.

Bass, L. N., D. C. Clark, and R. L. Sayers. 1966. Germination experiments with seed of Lesque- 
rella species. Proc. Assoc. Official Seed Analysts 56: $148-153$.

Black, M.. J. D. Bewley, and P. Halmer, eds. 2006. The Encyclopedia of Seeds Science, Technology and Uses. CAB International. Wallingford, UK. 828 p.

Cabin, R. J. and D. L. Marshall. 2000. The demographic role of soil seed banks in spatial and temporal comparisons of below and above ground populations of the desert mustard Lesquerella fendleri. J. Ecol. 88: 283-292.

Cabin, R. J., R. J. Mitchell, and D. L. Marshall. 1998. Do surface plant and soil seed bank populations differ genetically? A multipopulation study of the desert mustard Lesquerella fendleri (Brassicaceae). Am. J. Bot. 85: 1098-1109.

Chen. H. and M. A. Maun. 1999. Effects of sand burial depth on seed germination and seedling emergence of Cirsium pitcheri. Plant Ecol. 140: 53-60.

Claerbout, A. 2003. Survival strategies of two Illinois endangered plants: Lesquerella ludoviciana (silvery bladderpod) and Stylisma pickeringii var. pattersonii (patterson bindweed). M.Sc. thesis. Univ. Illinois at Urbana-Champaign, Urbana. IL.

Claerbout, A. E., J. M. Coons, H. R. Owen, and K. R. RobertSON. 2007. Floral biology of Physaria ludoviciana (Brassicaceae), a plant rare to the Midwest. Castanea 72: 130-137.

Crawley, M. J. 1992. Seed predators and plant population dynamics, p. 157-191. In M. Fenner [ed.], Seeds: the ecology of regeneration in plant communities. CAB International, Wallingford, UK. 384 p.

DELPH. L. F. 1986. Factors regulating fruit and seed production in the desert annual Lesquerella gordonii. Oecologia 69: 471-476.

Elberling, H. 2000. Spatiai pattern of Lesquerella arctica: Effects of seed bank and desiccation cracks. EcoSci. 7: 86-91

Evans, A. And R. Cabin. 1995. Can dormancy affect the evolution of post-germination traits? The case of Lesquerella fendleri. Ecology 76: 344-356.

FAndrich, L. AND C. Mallory-Smith. 2006. Jointed goatgrass (Aegilops cylindrica) seed germination and production varies by spikelet position on the spike. Weed Sci. 54: $443-451$.

Gleason. H. A. 1910. The vegetation of the inland sand deposits of Illinois. Bull. IL State Lab. Nat. Hist. 9: 23-174.

Grant, M. 2010. Survival strategies of the endangered Physaria ludoviciana (silvery bladderpod; Brassicaceae). M.Sc. thesis. Eastern Illinois Univ., Charleston, IL.

Herkert, J. R. and J. E. Ebinger. 2002. Endangered and Threatened Species of Illinois: Status and Distribution. Volume 1-Plants. Illinois Endangered Species Protection Board, Springfield, IL. 163 p.

Hyatt, L. A., A. S. Evans, and C. C. Baskin. 1999. Annual dormancy cycles in Lesquerella fendleri (Brassicaceae) seeds stored under both field and laboratory conditions. Can. J. Bot. 77: $1648-1654$.
Illinois Department of Natural Resources. 2010. Endangered and threatened species list. Retrieved May 23, 2011 from < http://dnr.state.il. us/ESPB/>

LAKON, G. 1949. The topographical tetrazolium method for determining the germinating capacity of seeds. Plant Physiol. 24: 389-394.

LoudA, S. M. 1989. Predation in the dynamics of seed regeneration, p. 25-51. In M. A. Leck, V. T. Parker, and R. L. Simpson [eds.], Ecology of soil seed banks. Academic Press, San Diego, CA.

Marchand, P. J. AND D. A. ROACH. 1980. Reproductive strategies of pioneering alpine species. seed production, dispersal, and germination. Arctic and Alpine Res. 12: 137-146.

Martinez, M. L. and P. Moreno-Casasola. 1993. Survival of seedling cohorts of a tropical legume on a sand dune system along the Gulf of Mexico: influence of germination date. Can. J. Bot. 71: 1427-1433.

MCClain, W. E. L. R. Phillippe, and J. E. EBINGER. 2005. Floristic assessment of the Henry Allan Gleason Nature Preserve, Mason County, Illinois. Castanea 70: 146-154.

Minnesota Department of Natural Resources. 1996. Endangered, threatened, special concern species-vascular plants-endangered. Retrieved May 23, 2011 from <http://files.dnr.state.mn. us/eco/nhnrp/endlist.pdf $>$

Parker, V. T., R. L. Simpson, and M. A. Leck. 1989. Pattern and process in the dynamics of seed banks, p. 367-384. In M. A. Leck, V. T. Parker, and R. L. Simpson [eds.]. Ecology of soil seed banks. Academic Press, San Diego, CA. 462 p.

Rabinowitz, D. 1981. Buried viable seeds in a North American tall-grass prairie: the resemblance of their abundance and composition to dispersing seeds. Oikos 36: 191-195.

Rollins. R. C. 1939. Studies in the genus Lesquerella. Amer. J. Bot. 26: 419-421.

Rollins, R. C. And E. A. Shaw. 1973. The Genus Lesquerella (Cruciferae) in North America. Harvard University Press, Cambridge, MA. 288 p.

Sharir, A. and H. Gelmond. 1971. Germination studies of Lesquerella fendleri and L. gordonii, with reference to their cultivation. Econ. Bot. 25: $55-59$.

Schwegman, J. E. 1973. Comprehensive plan for the Illinois Nature Preserves System. Part 2. The natural divisions of Illinois. Illinois Nature Preserves Commission, Rockford, IL. 32 p.

United States Department of Agriculture, Nat. ural Resources Conservation Service. 2010. The PLANTS database, version 3.5. National Plants Data Center, Baton Rouge, Louisiana, USARetrieved May 23, 2011 from <http:// plants.usda.gov>

Walck, J., J. Baskin, and S. Hidayati. 2005. Defining transient and persistent seed banks in species with pronounced seasonal dormancy and germination patterns. Seed Sci. Res. 15: 189-196.

Wisconsin Department of Natural Resources. 2004. Wisconsin endangered and threatened species laws and list. Retrieved May 23, 2011 from < http:// dnr.wi.gov/org/land/er/wlist/WI_ET_Laws_List.pdf> 